\title{
The Mediating Effects of Ego Resilience on the Relationship between Professionalism Perception and Technostress of Early Childhood Teachers
}

\author{
Sungwon Kim \\ Chongshin University, Seoul, South Korea \\ https:// orcid.org/0000-0003-4123-5204 \\ Jiyoung Lee \\ Tarlac State University, Tarlac, Philippines \\ https:// orcid.org/0000-0002-6972-1282
}

\begin{abstract}
The purpose of this study was to provide information regarding the effects of professionalism perception and ego resilience, the dependent variable and mediator respectively, on the technostress of early childhood teachers. The research subjects were 200 early childhood teachers teaching at kindergartens or childcare centers in Seoul or Gyeonggi Province. The data were analyzed through a reliability test, descriptive statistics, Pearson correlation, and structural equation modelling. Research findings were as follows: First, there were significant differences in professionalism perception by type of institution, teaching experience, education background and age of teachers, differences in technostress by type of institution, teaching experience, age of child in care, and age of teachers; and differences in ego resilience by type of institution and age of child in care. Second, there were negative correlations between professionalism perception and technostress, as with technostress and ego resilience, while there is a positive correlation between professionalism perception and ego resilience. Third, ego resilience has a mediating effect on the relationship between professionalism perception and technostress. The findings suggest that the effect of professionalism perception on technostress can be strengthened further by ego resilience.
\end{abstract}

Keywords: early childhood teacher; ego resilience; mediating effects; professionalism perception technostress

\section{Introduction}

Korean schools have recently postponed their on-campus start dates due to the Coronavirus pandemic, and have started the school year online (Price, 2020). Teleclasses, which were thought to be possible only decades in the future, have become a reality due to COVID-19 (Lee \& Shin, 2020). Students meet with teachers 
and friends through monitors and attend classes online. Students and teachers can freely access the necessary materials by using devices such as personal computers and smartphones, and submit assignments on subject content online (Collins, 2020; Zhong, 2020). Since the outbreak of COVID-19, utilizing a remote education system in the education field has now become a necessity, and is not an option anymore (Lee \& Shin, 2020). However, when teachers are unfamiliar with realtime online video programs, there may be problems with class management. Teachers employ various technological devices in this work, and those who have difficulty dealing with these technological devices or business applications experience stress (Lee, S. H., 2015).

Early childhood teachers also use these devices, and the internet, to perform educational or childcare tasks and administrative work, and to consult parents. In addition, early childhood teachers use multimedia teaching materials, including smart TVs and electronic blackboards, for large-group activities, such as story sharing for educational work (Lee \& Yang, 2016; Yoo et al., 2013). In Korea, kindergarten teachers use Nice and Edupine, and childcare teachers use integrated childcare information systems for administrative work (Lee, 2018a). Parent counselling methods are also adopting social media or smartphone apps (Lee, 2018b). A study that explored the possibility of remote kindergarten classes during the COVID-19 period reports that teachers provide play-related support for young children by posting videos, with content in line with the YouTube. The Kids Note app, which was previously used only as a means of information and notice delivery, is now used more actively by parents for uploading videos or photos of their children playing at home, on which teachers give feedback (Lee, 2020). In childcare centers, education on Coronavirus itself, and some activities, are being filmed by teachers and sent to parents. Afterwards, parents upload their child's home activities on Kids Note (Kim, 2020). Research shows that kindergartens and childcare centers are conducting similar forms of education. However, it has been reported that early childhood teachers are having difficulty using these tools at work, due to a lack of teacher training related to smart devices (Kim, 2017). Consequently, they can experience stress in the process of exposure and adaptation to new technologies.

Technostress, a term that combines technology and stress, was first proposed by Brod (1984). This term refers to the mental burden that arises from doing business by relying on information systems once technology has become part of the daily routine of an individual living in the information technology era. Tarafdar et al. (2007) expound further on the concept, by identifying the components of technostress, namely, techno-overload, techno-invasion, techno-complexity, techno-insecurity, and techno-uncertainty. Also, the stressed worker in the process of using technology experiences low job satisfaction, which has a negative effect on organizational productivity (Tarafdar at al., 2007). Other studies have also been conducted on teachers, such as on factors that influence environmental support variables, like TPACK (technological, pedagogical and content knowledge), and on school support and technostress (Joo et al., 2016). 
Technology is reported to be related to the development of professionalism. GessNewsome et al. (2003) found that teachers can enhance their professionalism by utilizing learning opportunities presented by e-learning. Considering that teachers use technology every day, Byrd (2017) proposes a technology-based platform for developing differentiated professionalism. In other words, technology can be used to enhance the professionalism of teachers, and it can be predicted that teachers with high levels of professionalism will have low levels of fear or stress about technology. Early childhood teachers' perceptions of professionalism are negatively correlated to job stress, and have a negative influence on it (Kim \& Cho, 2010; You \& Hwang, 2014). Based on previous findings, it can be inferred that there will be a significant relationship between the professionalism perception and technostress of early childhood teachers. In addition, the ego resilience of early childhood teachers is related to their professionalism perception (Hwang \& Kim, 2016; Park \& Jun, 2010), and it affects job stress (Jwa \& Oh, 2019; Kim \& Moon, 2016; Lee \& Lim, 2017). Overall, these findings suggest that ego resilience has a mediating effect between professionalism perception and technostress.

\section{Literature Review}

\subsection{Professionalism Perception}

Because of Korea's low birth rate, and women becoming more active in society, raising the national birth rate and supporting parenting has become a priority. This situation has led to a quantitative growth of childcare centers and a rapid increase in the number of teachers. Against this backdrop, the government recently implemented supporting policies, such as extensive spending to pay for childcare benefits and expanded free childcare. Such short-term quantitative expansion of childcare and early childhood education is likely to lead to a decline in the quality of education (Mo \& Kim, 2013). Considering that early childhood is a crucial period of physical, cognitive, social, and emotional development, and these developments are planned for, carried out, and greatly influenced by teachers (Mo \& Kim, 2013; Nicholson \& Reifel, 2011), teacher professionalism and teaching quality need to be enhanced, for the future benefit of society.

The professionalism of early childhood teachers is defined as the knowledge and skills that a childcare teacher must possess in order to provide high quality education and childcare. The actual teaching performance of early childhood teachers depends on the perception of their level of professionalism (Durkin, 1987; Hargreaves, 2000). Having such a perception of professionalism in one's job increases job satisfaction (Kim, 2005; Koo, 2004) and decreases stress (Kim, 2003; Myung, 2006). Other studies assert that professionalism perception is related to technostress (Gess-Newsome et al., 2003; Kim \& Lee, 2017). Perception of professionalism, especially regarding the sub-factors of work ethics, professional knowledge, and technical requirements, were the predictors of early childhood teachers' interaction with young children, reports Ku (2017). Shim and Shim's study (2019) found that teachers' professionalism perception affects children's internalization and externalization of problems. From existing literature regarding the topic, enhancing teachers' professionalism perception can, thus, be 
seen as critical, not only for the teacher's individual growth, but also for children's development.

\subsection{Technostress}

Technostress refers to negative psychological behaviors and attitudes caused directly or indirectly by technology (Weil \& Rosen, 1997). Ayyagari et al. (2011) describe technostress as the psychological inability to effectively handle information technology. Ragu-Nathan et al. (2008) define technostress as the stress caused by the dependency, working knowledge, user-level differences, and cultural change of information technology managers who work in conditions where they use new information technology. To sum up, technostress is a common symptom found in information technology workers. It is psychological pressure that arises from the difficulties caused by and inability to adapt to new information technology situations characterized by excessive amounts of information, and their inability to digest it. The devices people use often in their work - laptops, tablets, and smartphones - can increase technostress, especially when they are overused (Kim \& Shin, 2016; Lee et al., 2014). Tarafdar et al. (2007, p. 315) suggest five factors that constitute technostress, as shown in Table 1.

Table 1. Definitions of sub-factors of technostress

\begin{tabular}{|l|l|}
\hline Factor & Definition \\
\hline $\begin{array}{l}\text { Techno- } \\
\text { overload }\end{array}$ & $\begin{array}{l}\text { Increased work volume, faster work speed and changes in work habits } \\
\text { caused by new information technology }\end{array}$ \\
\hline $\begin{array}{l}\text { Techno- } \\
\text { invasion }\end{array}$ & $\begin{array}{l}\text { New information technology invading one's life, requiring one to } \\
\text { spend time on acquiring new technology }\end{array}$ \\
\hline $\begin{array}{l}\text { Techno- } \\
\text { complexity }\end{array}$ & $\begin{array}{l}\text { Lack of competence in learning technology or dealing with complex } \\
\text { new information technology }\end{array}$ \\
\hline $\begin{array}{l}\text { Techno- } \\
\text { insecurity }\end{array}$ & $\begin{array}{l}\text { Job anxiety caused by new-information-technology-induced job } \\
\text { anxiety, fear of being replaced by more skilled people }\end{array}$ \\
\hline $\begin{array}{l}\text { Techno- } \\
\text { uncertainty }\end{array}$ & Continuous change in new information technology \\
\hline
\end{tabular}

Çoklar et al. (2017) developed a teacher technostress scale, and present the factors involved as types of orientation: learning-teaching process, profession, technical, personal, and social. They found that teachers experienced high stress levels in technical issue orientation and social orientation. It has been reported that early childhood teachers also experience technostress (Kim \& Lee, 2017), and teachers experience stress when they are afraid of using technological devices at work (Lee \& Tsai, 2010). Based on these findings, this study aimed to examine the variables that predict technostress for early childhood teachers.

\subsection{Ego Resilience}

One of the factors that lowers teacher stress is termed ego resilience. Ego resilience refers to people's dynamic capacity to modify their level of self-control in response to the demanding characteristics of some environments. It has implications for one's adaptive or equilibrative abilities under conditions of environmental stress, uncertainty, conflict or disequilibrium (Block, 1993). The 
common conceptual feature of ego resilience is the ability to respond in a flexible way to stress caused by environmental difficulties (Choi et al., 2016). The ego resilience of early childhood teachers is a psychological characteristic that minimizes the effects of stress caused by various problems at educational institutions, and that maintains positive emotions during new experiences, thereby enabling effective teaching activities or problem-solving (Lee \& Pang, 2015). The ego resilience of early childhood teachers is negatively related to job exhaustion, and positivity - a sub-factor ego resilience - influences job exhaustion (Yang \& Paik, 2017). In addition, there are significant correlations between job stress, the quality of the program of educational institution, and ego resilience. Ego resilience of early childhood teachers plays a partially mediating role in the relationship between job stress and quality of program (Kim, 2018). To sum up, ego resilience is an influential variable in relation to stress and job exhaustion.

In this regard, the purpose of this study was to examine the effects of variables that affect stress caused by technology-based approaches to education in early childhood education, and to propose alternatives based on the results. To accomplish these objectives systematically, this study raised the following research questions:

1. Are there differences in the professionalism perception, technostress and ego resilience of the research respondents by personal background?

2. What are the relationships between teachers' professionalism perception, technostress, and ego resilience?

3. What is the mediating effect of ego resilience in the relationship between professionalism perception and technostress?

\section{Model}

This study was conducted to verify whether ego resilience has a mediating effect in the relationship between the professionalism perception and technostress of the early childhood teacher. In addition, the researchers investigated whether significant differences between each variable appear for type of institution, age of child in care, and teaching experience, education background and age of teacher.

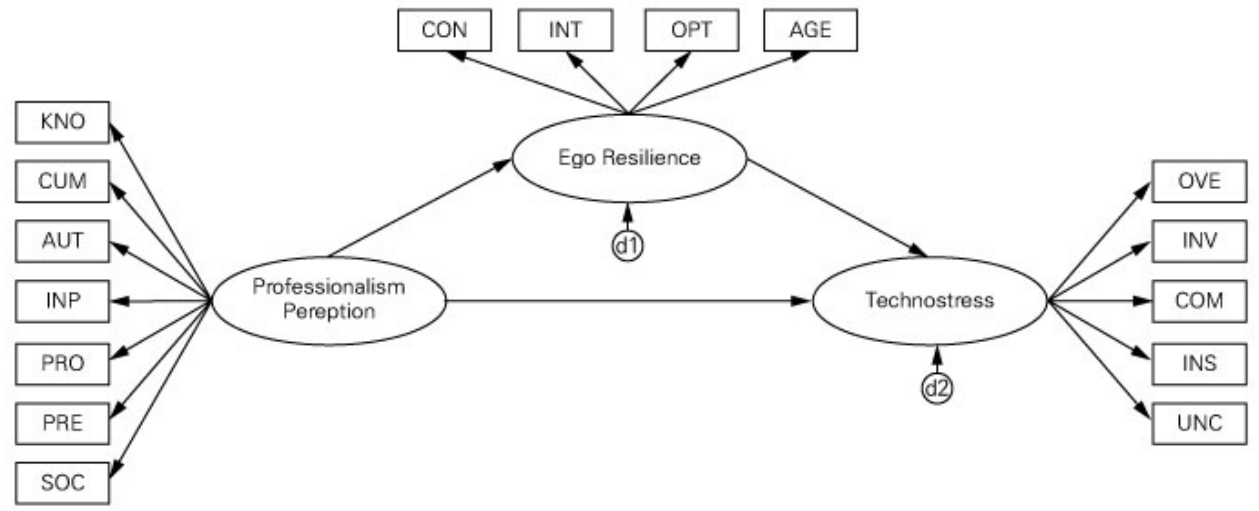

Note. KNO: Knowledge and skills, CUM: Community service, AUT: Autonomy, INP: The importance of education, PRO: Professional organization, PRE: Professional ethic, SOC: Socioeconomic status, CON: Confidence, INT: Interpersonal efficacy, OPT: Optimistic attitude, AGE: Anger control, OVE: Techno-overload, INV: Techno-invasion, COM: Techno-complexity, INS: Techno-insecurity, UNC: Techno-uncertainty

Figure 1: Research framework 


\section{Method}

\subsection{Respondents}

The number of study subjects was calculated using the $G^{*}$ Power selection number calculation program (Faul et al., 2007). The research respondents were 200 early childhood teachers working in kindergartens and childcare centers in Seoul and Gyeonggi Province, South Korea. The research data were collected through convenience sampling. Table 2 shows the results of frequency analysis to examine the demographic information of the research respondents.

Table 2. Demographic information

\begin{tabular}{|c|c|c|c|c|c|c|c|}
\hline & Category & $N$ & $\%$ & & Category & $N$ & $\%$ \\
\hline \multirow[t]{4}{*}{$\begin{array}{l}\text { Institution } \\
\text { type }\end{array}$} & $\begin{array}{l}\text { Private } \\
\text { childcare } \\
\text { center }\end{array}$ & 101 & 50.5 & \multirow[t]{4}{*}{$\begin{array}{l}\text { Teacher's } \\
\text { education }\end{array}$} & High school & 13 & 6.5 \\
\hline & $\begin{array}{l}\text { Public } \\
\text { childcare } \\
\text { center }\end{array}$ & 31 & 15.5 & & $\begin{array}{l}\text { College } \\
\text { (2 3years) }\end{array}$ & 82 & 41.0 \\
\hline & $\begin{array}{l}\text { Private } \\
\text { kindergarten }\end{array}$ & 62 & 31.0 & & $\begin{array}{l}\text { University }(4 \\
\text { years) }\end{array}$ & 81 & 40.5 \\
\hline & $\begin{array}{l}\text { Public } \\
\text { kindergarten }\end{array}$ & 6 & 3.0 & & $\begin{array}{l}\text { Graduate } \\
\text { school }\end{array}$ & 24 & 12.0 \\
\hline \multirow{4}{*}{$\begin{array}{l}\text { Teaching } \\
\text { experience }\end{array}$} & Under 5 years & 83 & 41.5 & \multirow{4}{*}{$\begin{array}{l}\text { Teacher's } \\
\text { age }\end{array}$} & $20 \mathrm{~s}$ & 61 & 30.5 \\
\hline & $6 \sim 10$ years & 69 & 34.5 & & $30 s$ & 88 & 44.0 \\
\hline & 11 15 years & 34 & 17.0 & & $40 \mathrm{~s}$ & 43 & 21.5 \\
\hline & Over 16 years & 14 & 7.0 & & $50 \mathrm{~s}$ & 8 & 4.0 \\
\hline \multirow{3}{*}{$\begin{array}{l}\text { Child's } \\
\text { age }\end{array}$} & 3 years & 71 & 35.5 & & & & \\
\hline & 4 years & 84 & 42.0 & & & & \\
\hline & 5 years & 45 & 22.5 & & & & \\
\hline \multicolumn{2}{|c|}{ Total } & 200 & 100.0 & \multicolumn{2}{|c|}{ Total } & 200 & 100.0 \\
\hline
\end{tabular}

\subsection{Measures}

Professionalism perception. To measure the professionalism perception of early childhood teachers, a scale originally developed by Lindsay and Lindsay (1984), revised and supplemented by Wi (2008), was used. The sub-factors of this scale are knowledge and skills (4 items), social service (4 items), autonomy (4 items), the importance of education (3 items), professional organizations (3 items), work ethics ( 3 items), and socio-economic status (4 items). There are 25 items in total, which are measured with a 5-point Likert scale. The higher the score, the higher the perception of one's professionalism as an early childhood teacher, and vice versa. In this study, Cronbach's a values were knowledge and skills 0.76 , social service 0.79 , autonomy 0.75 , importance of education 0.83 , professional organizations 0.85 , vocational ethics 0.76 , social and economic status 0.73 , and overall, 0.92 .

Technostress. To measure the technostress of early childhood teachers, the technostress scale developed by Tarafdar et al. (2007), modified and supplemented by Lee (2017), was used. The sub-factors of this scale are techno- 
overload (5 items), techno-invasion (4 items), techno-complexity (5 items), technouncertainty (5 items), and techno-insecurity ( 4 items). There are 23 items in total, measured with a 4-point Likert scale. A higher score means teachers' technostress is high. In this study, Cronbach's a values were techno overload .76, technoinvasion .87 , techno-complexity .89 , techno-insecurity .85 , techno-uncertainty .87 , and overall, .91 .

Ego resilience. To measure ego resilience of early childhood teachers, Klohnen's (1996) scale, translated by Park (1996) and used in E. S. Lee's study (2015), was used. The sub-factors of this scale are confidence (7 items), efficiency of interpersonal relationships (7 items), optimistic attitude (7 items), and anger control ( 2 items). There are 23 items in total, that are measured with a 5-point Likert scale. A higher score means teachers' ego resilience is high. In this study, Cronbach's a values were confidence .85 , efficacy of interpersonal relationships .93 , optimistic attitude .93 , anger control .75, and overall, .95 .

\subsection{Data Analysis}

Data analysis in this study was conducted using the SPSS 22.0 program and the AMOS 24.0 program. The procedures for research analysis were as follows. First, the mean value, distribution, and standard deviation and normality test of each variable were confirmed by descriptive statics, and the differences according to personal background were checked through t-tests and one-way ANOVA. Pearson's correlation analysis was used to verify the correlations between variables. Second, the research model was constructed and analyzed by applying a structural equation model. The structural equation model has the advantage of being able to control measurement error by using common variances extracted using multiple measured variables as latent variables, and making it easier to use mediating variables (Kim et al., 2009). Model fit verification was determined by model fit indices, such as $\chi^{2}$, GFI, TLI, CFI, and RMSEA. The mediating effects of ego resilience on professionalism perception and technostress were tested by the bootstrapping method.

\section{Result}

\subsection{Descriptive Statistics}

The mean of professionalism perception is $3.61( \pm .45)$, the mean of technostress is $2.40( \pm .33)$ and the mean of ego resilience is $3.82( \pm .50)$. Kline (2005) suggests that the normality assumption cannot be satisfied when the absolute value of the skewness is 3.0 or more, and the kurtosis value is 10.0 or more. In this study, skewness was between -.66 and .70, and kurtosis was between -.78 and 2.70, which satisfied the normality assumption.

\subsection{Group Difference Analysis}

The differences in professionalism perception according to type of institution, teaching experience, age of child in care, and education background and age of teachers are shown in Table 3 . The professionalism perception of early childhood teachers was significantly different by type of institution $(F=3.89, p<.05)$, and posthoc analysis showed that the professionalism perception of public childcare center teachers was higher than those of private kindergartens. Differences in 
professionalism perception of early childhood teachers also appeared by teaching experience $(F=2.71, p<.05)$. There was also a difference in professionalism perception by education background $(F=4.65, p<.01)$, and post-hoc analysis showed that professionalism perception of high school graduates was significantly lower than counterparts in other groups. Differences in professionalism perception also appeared according to the age of the teacher $(F=8.43, p<.001)$, and post-hoc analysis showed that professionalism perception of teachers in their 20s and 30s was significantly higher than that of teachers in their 40s.

There was a significant difference in the technostress of early childhood teachers by the type of institution $(F=6.36, p<.001)$, and post-hoc tests showed that the technostress of teachers working in private childcare centers was higher than that of teachers at public centers, and that of private kindergarten teachers. There was a significant difference in the technostress of early childhood teachers by teaching experience $(F=7.95, p<.001)$. The score of teachers with $6 \sim 10$ years of teaching experience was higher than that of teachers with less than 5 years and 11 15 years of teaching experience. There was a significant difference in the technostress by the age of children $(F=4.78, p<.01)$. The score of teachers teaching 3 -year-olds was higher than that of teachers of 4-year-olds. Technostress differed significantly according to the age of teacher $(F=8.67, p<.001)$, and the scores of teachers in their 30s and 40s were higher than that of teachers in their 20s.

Results show a significant difference in ego resilience according to the type of institution $(F=4.03, p<.01)$. Post-hoc tests showed that the ego resilience of teachers working in private childcare centers and public childcare centers was higher than that of teachers working in kindergartens. There was a significant difference in the ego resilience of early childhood teachers according to the age of children in their care $(F=5.21, p<.01)$. The ego-resilience of teachers teaching 3-year-old children was higher than that of teachers of 5-year-olds. There was a significant difference in the ego resilience of early childhood teachers according to the age of the teacher $(F=5.18, p<.01)$, and a post-hoc test showed that the ego resilience of teachers in their 20s was significantly higher than that of teachers in their 30s and 40s.

Table 3. Differences by teachers' personal backgrounds

\begin{tabular}{|c|c|c|c|c|c|}
\hline \multirow{2}{*}{\multicolumn{2}{|c|}{ Category }} & \multirow{2}{*}{$\mathbf{N}$} & $\begin{array}{l}\text { Profession- } \\
\text { alism }\end{array}$ & $\begin{array}{c}\text { Techno- } \\
\text { stress }\end{array}$ & $\begin{array}{c}\text { Ego } \\
\text { resilience }\end{array}$ \\
\hline & & & $M(S D)$ & $M(S D)$ & $M(S D)$ \\
\hline \multirow{4}{*}{$\begin{array}{l}\text { Type of } \\
\text { institution }\end{array}$} & Private childcare centera & 101 & $3.65(.44)$ & $2.50(.25)$ & $3.88(.38)$ \\
\hline & Public childcare centerb & 31 & $3.78(.40)$ & $2.28(.26)$ & $3.97(.39)$ \\
\hline & Private kindergarten $^{c}$ & 62 & $3.47(.46)$ & $2.33(.40)$ & $3.66(.67)$ \\
\hline & Public kindergarten $^{\mathrm{d}}$ & 6 & $3.56(.31)$ & $2.26(.40)$ & $3.65(.40)$ \\
\hline \multicolumn{3}{|c|}{$\begin{array}{c}F \\
\text { Turkey }\end{array}$} & $3.89^{*} \quad c<b$ & $\begin{array}{l}6.36^{* * *} \\
b, c<a\end{array}$ & $\begin{array}{c}4.03^{* *} \quad c<a, \\
b\end{array}$ \\
\hline & Under 5 years ${ }^{a}$ & 83 & $2.35(.31)$ & $2.35(.31)$ & $3.85(.60)$ \\
\hline
\end{tabular}




\begin{tabular}{|c|c|c|c|c|c|}
\hline \multirow{5}{*}{$\begin{array}{l}\text { Teaching } \\
\text { experience }\end{array}$} & \multirow{2}{*}{ Category } & \multirow{2}{*}{$\mathbf{N}$} & $\begin{array}{l}\text { Profession- } \\
\text { alism }\end{array}$ & $\begin{array}{l}\text { Techno- } \\
\text { stress }\end{array}$ & $\begin{array}{c}\text { Ego } \\
\text { resilience }\end{array}$ \\
\hline & & & $M(S D)$ & $M(S D)$ & $M(S D)$ \\
\hline & $6 \sim 10$ years $^{b}$ & 69 & $2.53(.29)$ & $2.53(.29)$ & $3.82(.39)$ \\
\hline & $11 \sim 15$ yearsc $^{c}$ & 34 & $2.25(.39)$ & $2.25(.39)$ & $3.82(.22)$ \\
\hline & 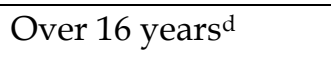 & 14 & $2.46(.16)$ & $2.46(.16)$ & $3.60(.79)$ \\
\hline & $\begin{array}{c}F \\
\text { Turkey }\end{array}$ & & $2.71^{*}$ & $\begin{array}{l}7.95^{\text {***}} \\
\mathrm{a}, \mathrm{c}<\mathrm{b}\end{array}$ & 99 \\
\hline Age of & 3 years $^{a}$ & 71 & $3.60(.42)$ & $2.48(.30)$ & $3.95(.32)$ \\
\hline $\begin{array}{l}\text { child in } \\
\text { care }\end{array}$ & 4 years $^{b}$ & 84 & $3.67(.40)$ & $2.32(.35)$ & $3.80(.53)$ \\
\hline & 5 years $^{c}$ & 45 & $3.53(.55)$ & $2.44(.28)$ & $3.65(.62)$ \\
\hline & $\begin{array}{c}F \\
\text { Turkey }\end{array}$ & & 1.59 & $4.78^{* *} \quad b<a$ & $5.21^{* *} \quad c<a$ \\
\hline Education & High schoola $^{\mathrm{a}}$ & 13 & $3.18(.08)$ & $2.60(.02)$ & $3.88(.04)$ \\
\hline & College (2 3years) ${ }^{b}$ & 82 & $3.62(.27)$ & $2.36(.24)$ & $3.90(.36)$ \\
\hline & University (4years) $^{\mathrm{c}}$ & 81 & $3.66(.56)$ & $2.43(.40)$ & $3.74(.63)$ \\
\hline & Graduate studies $^{\mathrm{d}}$ & 24 & $3.64(.51)$ & $2.37(.37)$ & $3.78(.55)$ \\
\hline & $\begin{array}{c}F \\
\text { Turkey }\end{array}$ & & $\begin{array}{c}4.65^{* *} \\
a<b, c, d\end{array}$ & 2.43 & 1.55 \\
\hline Age of & $20 \mathrm{~s}^{\mathrm{a}}$ & 61 & $3.76(.45)$ & $2.34(.27)$ & $3.99(.59)$ \\
\hline teacher & $30 \mathrm{~s}^{\mathrm{b}}$ & 88 & $3.65(.41)$ & $3.35(.37)$ & $3.76(.39)$ \\
\hline & $40 \mathrm{~s}^{\mathrm{c}}$ & 43 & $3.35(.43)$ & $3.62(.23)$ & $3.65(.53)$ \\
\hline & $50 s^{d}$ & 8 & $3.48(.04)$ & $3.41(.07)$ & $4.00(.00)$ \\
\hline & $\begin{array}{c}F \\
\text { Turkey }\end{array}$ & & $\begin{array}{c}8.43^{* * *} \quad c<a \\
b\end{array}$ & $\begin{array}{c}8.67^{* * *} \mathrm{a}<\mathrm{b}, \\
\mathrm{c}\end{array}$ & $\begin{array}{l}5.18^{* *} \\
b, c<a\end{array}$ \\
\hline
\end{tabular}

${ }^{*} p<.05,{ }^{* * *} p<.01,{ }^{* * *} p<.001$

\subsection{Correlation Analysis}

Correlation analysis was performed to examine the relationships among professionalism perception, technostress, and ego resilience. Professionalism perception showed a significant negative correlation with technostress $(r=-.41$, $p<.001)$ and a significant positive correlation with ego resilience $(r=.64, p<.001)$. Technostress showed a significant negative correlation with ego resilience $(r=-.43$, $p<.001)$, as shown in Table 4.

Table 4. Correlations between variables

\begin{tabular}{lccc}
\hline & 1 & 2 & 3 \\
\hline 1. Professionalism perception & - & & \\
\hline 2. Technostress & $-.41^{* *}$ & - & \\
\hline 3. Ego resilience & $.64^{* * *}$ & $-.43^{* \star *}$ & - \\
\hline
\end{tabular}
$* * * p<.001$ 


\subsection{Mediating Effects Analysis}

Each of the criteria of the goodness of fit was met, as shown in Table 5. As a result of the analysis of the measurement model, $\chi^{2}=205.143(p=.000), \mathrm{GFI}=.895, \mathrm{TLI}=.909$, $\mathrm{CFI}=.933$, RMSEA $=.079$, most of the fits met the criteria.

Table 5. Summaries of model fit

\begin{tabular}{ccccccccc}
\hline CMIN & $d f$ & CMIN/df & RMSEA & AGFI & GFI & CFI & NFI & TLI \\
\hline 205.143 & 88 & 2.331 & .079 & .837 & .895 & .933 & .890 & .909 \\
\hline
\end{tabular}

The path statistics shown in Figure 2 are standardized regression weights. Figure 2 offers support for the indirect effects of the model of childcare teachers' professionalism perception in relation to technostress. The figure indicates that childcare teachers' professionalism perception affects ego resilience. There was an indirect effect of ego resilience on technostress. The path coefficients and the result of examining hypothesized mediating effects are presented in Table 6.

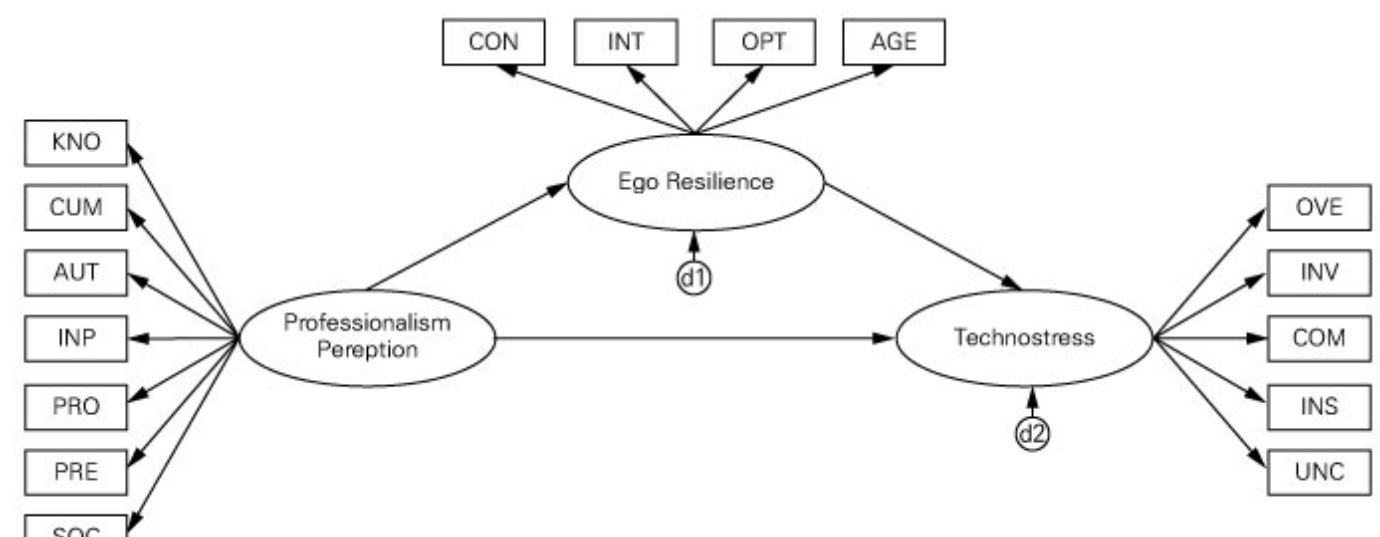

Figure 2. Structural modeling

Table 6. Mediation effects of ego resilience

\begin{tabular}{|l|c|c|c|c|}
\hline \multirow{2}{*}{ Model/Hypothesized Path } & \multirow{2}{*}{ Beta } & \multirow{2}{*}{$p$} & \multicolumn{2}{|c|}{$95 \%$ Confidence } \\
\cline { 4 - 5 } & & & LB & UB \\
\hline Full Mediation & & & & \\
\hline $\mathrm{PP} \rightarrow \mathrm{ER} \rightarrow \mathrm{TS}$ & -.268 & .010 & & \\
\hline Direct Model & & & & \\
\hline $\mathrm{PP} \rightarrow \mathrm{TS}$ & -.153 & .021 & & \\
\hline Std. Indirect Effect (ER) & -.115 & .010 & -.184 & -.051 \\
\hline
\end{tabular}

Note. PP professionalism perception, ER ego resilience, TS technostress.

The results in Table 6 show that there is a significant relationship between professionalism perception and technostress, if a standardized total effect of -.153 $(p<.05)$ is used. In other words, the total effect of professionalism perception as independent variable on technostress as dependent variable, without the inclusion of ego resilience as mediator variable, was statistically significant. 
This relation remains insignificant after the inclusion of ego resilience in the model. With a standardized direct effect of $-.268(p<.05)$, the direct effect of professionalism perception as independent variable on technostress as dependent variable, with the inclusion of ego resilience as mediating variable, was statistically significant. Further mediation effects on technostress through ego resilience, with the standardized indirect effect of -.115 $(p<.05)$ with LB -.184 and UB -.051, and mediation of ego resilience, was partial mediation.

\section{Discussion}

This section will discuss the results of this study. First, differences were found in professionalism perception depending on type of institution, teaching experience, education background, and age of teacher. These results correspond, in part, with No's (2013) finding that the professionalism perception of early childhood teachers differed depending on age, marital status, academic background, and age of children being taught, with high scores at 31 years of age or older, married, four-year college degree or higher, and infant class teachers. The findings that the teaching experience of early childhood teachers directly affects their professional development, and their educational background indirectly affects professional development through self-supervision and role-playing (Kim \& Lee, 2008), also provides a rationale for the findings of this study.

Differences were found in technostress by type of institution, teaching experience, age of children taught, and age of teacher. Teachers at private childcare centers and those who have 6-10 years teaching experience, who are in their 30s and 40s, and in charge of 3-year-olds had technostress. These findings are partially in line with the literature, namely that there is a difference in technostress depending on the age of children being taught, and the certification of the teacher. In particular, infant and childcare teachers and kindergarten teachers with second-class licenses registered higher technostress than kindergarten teachers with first-class licenses (Kim \& Lee, 2017). The results were also supported by the assertion that older people showed higher technostress than younger people (Kim \& Chung, 2017).

Differences in ego resilience were found by type of institution, age of children being taught, and age of teacher. It was higher for childcare center teachers, teachers of 3-year-olds, and teachers in their 20s. These results are inconsistent with a result found by Park et al. (2018), that there was no difference in resilience between kindergarten and childcare center teachers, and that those aged 36 to 40 were more resilient than those aged 26 to 30 . The results of this current study imply that, when planning teacher education related to professionalism perception, technostress, and ego resilience, factors related to type of institution, teaching experience, age of child in care, education background, and age of teacher should be considered.

Second, professionalism perception showed a negative correlation with technostress and a positive correlation with ego resilience. In addition, technostress showed a negative correlation with ego resilience. Similarly, the study of Kilınç et al. (2015) found a negative correlation between teacher 
professionalism and perceived stress. The result of this current study is consistent with the finding of You and Hwang (2014), that the professionalism perception of early childhood teachers showed a positive correlation with ego resilience. It is also in keeping with the result reported by a study by Elzohary et al. (2017), that there is a negative correlation between perceived stress and ego resilience.

Third, ego resilience has a mediating effect on the relationship between professionalism perception and technostress. This is partially consistent with previous studies that argue that early childhood teachers' professionalism perception has a significant effect on stress (Kim \& Cho, 2010; Yoo \& Hwang, 2014). The result is also supported by a study by Sandilos et al. (2018), which considered professional development as a variable to lower the stress of teachers. The result of the current study is partially consistent with the finding that the professionalism perception of early childhood teachers had a significant effect on ego resilience (Hwang \& Kim, 2016; Park \& Jun, 2010), and similar to the finding that the ego resilience of early childhood teachers had a significant effect on stress (Lee \& Lim, 2017; Jwa \& Oh, 2019). Studies examining the relationship between job stress and self-resilience report that the job stress of self-flexible teachers was relatively low (Kim \& Hong, 2013; Yoo \& Hwang, 2014). In other words, people with high ego resilience have a high regulatory ability to strengthen or weaken their level of tension and impatience, depending on the situation, so, they adapt successfully by responding flexibly to changing situational demands. People with low resilience, in contrast, have low control and lack flexibility in stressful situations, so, they cannot cope effectively (Block \& Block, 1980; Block \& Kremen, 1996). Based on these findings, the researchers recommend planning programs to increase ego resilience levels, in order to lower the technostress experienced by early childhood teachers.

\section{Limitations}

First, the data in this study were collected in a self-reporting manner using questionnaires. It is possible that the research respondents could have failed to express their experiences and feelings sufficiently. Conducting in-depth studies through various qualitative methods, such as case studies, in-depth interviews, and participation observation, is recommended. Second, the technostress scale used in this study is one developed for the general public. Therefore, developing and using a technostress scale specifically for early childhood teachers could be helpful to expand understanding of their technostress, specifically.

\section{Recommendations}

This study is meaningful in that it empirically analyzed the relationship between technostress and related variables. By contextualizing the results in an early childhood education setting, educational programs for enhancing professionalism need to be developed as the way to reduce the technostress of teachers, and to help them perform their roles more effectively. Plans to enhance teachers' ego resilience, so that they can cope with technostress flexibly, need to be explored. 


\section{Conclusion}

In this study, the differences in professionalism perception, technostress, and ego resilience, based on teachers' personal backgrounds, correlations among variables, and the mediating effect of ego resilience on professionalism perception and technostress of early childhood teachers, were examined. The difference validation shows that the type of institution, the age of teachers, and the age of children in care are important factors that cause variability. The application of technology in the field of education continues to increase rapidly. This is especially true at this point in time, when, due to COVID-19, online teacher education is requested for support (Park \& Bae, 2020), video clips of educational content and activities are being filmed, and social network service-based communication with parents are being strengthened for early childhood education. Therefore, this study is significant in that it was conducted at a time when remote classes became common. Considering this shift and the needs of the times, exploring alternatives to lower the technostress of early childhood teachers is essential, to ensure the successful application of technology and the delivery of quality early childhood education. Therefore, studies regarding teacher technostress need to be continuously conducted.

\section{References}

Ayyagari, R., Grover, V., Purvis, R. (2011). Technostress: Technological antecedents and implications. MIS Quarterly, 35(4), 831-858. https://doi.org/10.2307/41409963

Block, J. (1993, March 25-28). Ego-resilience through time [Paper presentation]. The biennial meeting of the Society for Research in Child Development, New Orleans, LA.

Block, J. H., \& Block, J. (1980). The role of ego-control and ego-resiliency in the organization of behavior. In W. A. Collins (Ed.), Development of cognition, affect and social relations: The Minnesota symposia on child psychology, Vol. 13 (pp. 39-101). Erlbaum.

Block, J., \& Kremen, A. M. (1996). IQ and ego-resiliency: Conceptual and empirical connections and separateness. Journal of Personality and Social Psychology, 70(2), 349-361. https://doi.org/10.1037/0022-3514.70.2.349

Brod, C. (1984). Technostress: The human cost of the computer revolution. Addison-Wesley.

Byrd, N. (2017). Technology-based professional development for teaching and learning in K-12 classroom [Doctoral dissertation, Walden University].

Choi, Y. H., Je, G. D., \& Kim, B. G. (2016). Yeong-yua gyoyuggigwan jongsajaui jaatanlyeogseong-i jigmumanjogdo-e michineun yeonghyang [Influence of ego resilience on job satisfaction for those working at early childhood care and education institutions]. Korean Local Autonomy Research, 18(1), 27-52. https:// doi.org/10.5807/kjohn.2016.25.4.268

Çoklar, A. N., Efilti, E., \& Sahin, Y. L. (2017). Defining teachers' technostress levels: A scale development. Journal of Education and Practice, 8(21), 28-41.

Collins, C. (2020, March 19). Teaching through Coronavirus: What educators need right now. Teaching Tolerance. https://www.tolerance.org/magazine/teachingthrough-coronavirus-what-educators-need-right-now

Durkin, D. (1987). A classroom-observation study of reading instruction in kindergarten. Early Childhood Research Quarterly, 2(2), 275-300. https://doi.org/10.1016/08852006(87)90036-6

Elzohary, N. W., Mekhail, M. N., Hassan, N. I., Menessy, R. F. M. (2017). Relationship between ego resilience, perceived stress and life satisfaction among faculty 
nursing students. Journal of Nursing and Health Science, 6(7), 57-70. https://doi.org/10.9790/1959-0606075770

Faul, F., Erdfelder, E., Lang, A., \& Buchner, A. (2007). G*Power 3: a flexible statistical power analysis program for the social, behavioral, and biomedical sciences. Behavior Research Methods, 39(2), 175-191. https:// doi.org/10.3758/bf03193146.

Gess-Newsome, J., Blocher, M., Clark, J., Menasco, J., \& Willis, E. (2003). Technology infused professional development: A framework for development and analysis. Contemporary Issues in Technology and Teacher Education, 3(3), 324-340. https://www.learntechlib.org/primary/p/19910/

Hargreaves, A. (2000). Four ages of professionalism and professional learning. Teachers and Teaching: Theory and Practice, 6(2), 151-182. https://doi.org/10.1080/713698714

Hwang, Y. S., \& Kim, K. I. (2016). Boyug gyosaui jagigaebal-yoggu, jeonmunseong-insig, jaatanlyeogseong mich yunliuisig gan-ui gwangye bunseog [Relationship between self-development desire, expertise, self-resilience and ethical consciousness of childcare teachers]. [Paper presentation] The conference of The Korean Society For Early Childhood Education, Seoul, Korea.

Joo, Y. J., Lim, K. Y., \& Kim, N. H. (2016). Gyosuhwaldong-eseo tekeunolloji suyong-uido yeonghyang byeon-in-e gwanhan yeongu [The effects of secondary teachers' technostress on the intention to use technology in South Korea]. Computers $\mathcal{E}$ Education, 95(1), 114-122. https://doi.org/10.1016/j.compedu.2015.12.004

Jwa, S. H., \& Oh, J. H. (2019). Boyuggyosaui hoebogtanlyeogseong-i jigmuseuteuleseue michineun yeonghyang: wonjang-ui gamseongjeog lideosib-ui maegaehyogwa [The effect of day care center teachers' resilience on job stress: the mediating effect of directors' emotional leadership]. The Journal of Learner-Centered Curriculum and Instruction, 19(10), 457-476. https://doi.org/10.22251/jlcci.2019.19.10.467

Kılınç, A. Ç., Cemaloğlu, N., \& Savaş, G. (2015). The relationship between teacher leadership, teacher professionalism, and perceived stress. Eurasian Journal of Educational Research, 58, 1-26. https://doi.org/10.14689/ejer.2015.58.5

Kim, A. N. (2018). Yuagyosaui jigmuseuteuleseuwa peulogeulaem jil-ui gwangyeeseo jagitanlyeogseong-ui maegaehyogwa [The mediating effect of self-resilience on the relationship between job stress and program quality of early childhood teachers]. Learner-centered Curriculum and Instruction Research, 18(2), 319-336. https://doi.org/10.22251/jlcci.2018.18.2.319

Kim, B. H. (2017). Yua yeonlyeong-e ttaleun ICThwal-yong-gyoyug-e gwanhan yuagyosadeul-ui insig mich un-yeongsiltae [Early childhood teachers' perceptions and practices of ICT education by age of children]. Learner-Centered Curriculum and Instruction Research, 17, 287-314. https://doi.org/10.22251/jlcci.2017.17.5.287

Kim, D. E., \& Shin, J. (2016). The impacts of smartphone addiction and technostress on customer satisfaction and loyalty. International Journal of Security and Its Applications, 10(12), 409-418. https://doi.org/10.14257/ijsia.2016.10.12.34

Kim, H. J., \& Chung, J. S. (2017). Gyosaui tekeunolloji hwal-yong yeonghyang byeon-in gan-ui gujojeog gwangye mich jojeol hyogwa geomjeung [Structural relationships and moderator effects among factors affecting technology use among teachers]. Journal of Educational Technology, 33(1), 35-73. https://doi.org/10.17232/KSET.33.1.035

Kim, J. H., Kim, M. G., \& Hong, S. H. (2009). Writing a paper with a structural equation model. Communication Books.

Kim, M. S., \& Moon, H. S. (2016). Yuagyosaui hoebogtanlyeogseong, wanbyeogjuui seonghyang, geunmuhwangyeong-insig-i jigmuseuteuleseue michineun 
yeonghyang bunseog [The effects of early childhood teachers' resilience, perfectionism and work environment perception on job stress]. Early Childhood Education Research \& Review, 20(2), 53-73.

Kim, O. J., \& Cho, H. J. (2010). Yeong-agyosaui jeonmunseong insiggwa boyugsiseol jojigmunhwagajigmuseuteuleseue michineun yeonghyang [The effect of infant teachers' professionalism awareness and the organizational culture at childcare centers on teacher job stress]. Korean Journal of Early Childhood Education, 30(2), 193209. https://doi.org/10.18023/kjece.2010.30.2.009

Kim, R. J., \& Hong, Y. A. (2013). Boyuggyosaui jaatanlyeogseong-gwa simlijeog annyeonggam-i jigmuseuteuleseue michineun yeonghyang [The influence of ego-resilience and psychological well-being on job stress of childcare teachers]. Journal of Korean Child Care and Education, 9(4), 55-74. https:// doi.org/10.14698/jkcce.2013.9.4.055

Kim, S. M., \& Lee, J. S. (2008). Yuagyosaui jeonmunseong-gwa gwanlyeondoen byeonindeul gan-ui gujomohyeong bunseog: gyosaui haglyeog, gyeonglyeog, yeoghalsuhaeng, jagijanghag-eul jungsim-eulo [Analysis of structure model between variables related the teacher professionalism: Focused on teacher educational background, job experiences, role performance, and self-supervision]. Korean Journal of Early Childhood Education and Care, 1(1), 15-23.

Kim, S. W. (2020). Early childhood education support in Korea amid the COVID-19 pandemic. Universal Journal of Educational Research, 8(8), 3310-3322.

Kim, S. W., \& Lee, J. Y. (2017). Yeong-yuagyosaui tekeuno seuteuleseu, donglyo gwangye, jeonmunseong insig-i gyosu hyoneung-gam-e michineun yeonghyang [The effects of technostress, colleague relationships, and professionalism awareness on teaching efficacy of early childhood teachers]. Journal of Early Childhood Education, 37(5), 247-269. https://doi.org/10.18023/kjece.2017.37.5.011

Kim, S. Y. (2005). Eolin-ijib boyuggyosaui jeonmunseong insiggwa jigmumanjogdowaui gwangye [Professionalism and job satisfaction of teachers in nursery school] [Master's thesis, Konkuk University].

Kim, Y. J. (2003). Yeong-aboyuggyosaui jeonmunseong insiggwa jigmuseuteuleseue gwanhan yeongu [A study on infant nursing teachers' recognition of professional and job stress] [Master's thesis, Duksung Women's University].

Kim, Y. J. (2003). A study on infant nursing teacher's recognition of professional and job stress [Master's thesis, Duksung Women's University].

Kline, R. B. (2005). Principles and practice of structural equation modeling (2nd ed.). Guilford Press.

Klohnen, E. C. (1996) Conceptual analysis and measurement of the construct of egoresiliency. Journal of Personality and Social Psychology, 70(5), 1067-1079. https://doi.org/10.1037/0022-3514.70.5.1067

Koo, E. M. (2004). Boyug peulogeulaem-ui jil-e yeonghyang-eul michineun gyosa gwanlyeon byeon-in bunseog [An analysis of teacher-related variables affecting the quality of childcare programs] [Doctoral dissertation, Sookmyung Women's University].

Ku, J. Y. (2017). Yuagyosaui jeonmunseong insiggwa jigmuseuteuleseuga gyosawa yua gan sanghojag-yong-e michineun yeonghyang [The effects of professionalism awareness and occupational stress on teacher and child interactions in early childhood teachers]. Journal of the Korean Society of Science and Technology, 18(6), 470-477. https://doi.org/10.5762/KAIS.2017.18.6.470

Lee, D. Y. (2020, December 17). Kolona19lo hyeonsilhwahan wongyeogsueob...sasang choyu onlaingaehag [Teleclasses realised as Covid-19: The first online school in history] Yonhap https://www.yna.co.kr/view/AKR20201216118200530

Newspaper. 
Lee, E. S. (2015). Boyuggyosaui jaatanlyeogseong, jigmuseuteuleseu, boyughyoneunggam, boyugheonsin mich haengboggam gan-ui gujojeog gwangye [The structural relationships among childcare teachers' self-resilience, childcare efficacy, job stress, devotion and happiness] [Doctoral dissertation, Dong-A University].

Lee, J. H., \& Lim, J. H. (2017). Boyuggyosaui hoebogtanlyeogseong-gwa sahoejeog jijiga jigmuseuteuleseue michineun yeonghyang. [The effects of childcare teachers' resilience and social support on job stress]. Early Childhood Education \& Care, 12(4), 197-214.

Lee J. Y. (2018a). Yuagyosaui tekeunoseuteuleseuwa gyosahyoneung-gam-ui gwangyeeseo seuteuleseudaecheoui maegaehyogwa.[Mediating effect of stress coping in the relationship between technostress and teacher efficacy of early childhood teachers]. Korean Journal of Stress Research, 26, 46-51. https://doi.org/10.17547/kjsr.2018.26.1.46

Lee J. Y. (2018b). Yuagyosaui tekeunoseuteuleseuwa seumateupon jungdoggyeonghyangui gwangye: gyosahyoneung-gamgwa dijiteol ditogseuui ijung maegaehyogwa [The relationship between technostress and smartphone addiction tendency among early childhood teachers: Dual mediating effects of teacher efficacy and digital detox]. The Journal of Humanities and Social Sciences, 21(9), 977-992. https://doi.org/10.22143/HSS21.9.6.70

Lee, M. H., \& Tsai, C. C. (2010). Exploring teachers' perceived self-efficacy and technological pedagogical content knowledge with respect to educational use of the World Wide Web. Instructional Science, 38, 1-21. https://doi.org/10.1007/s11251-008-9075-4

Lee, M. J. (2020). Yuchiwon wongyeogsueob ganeungseong tamsaeg-eul wihan silhaengyeongu [Action research for exploring the possibility of distance learning in kindergarten] [Master's thesis, Sahmyook University].

Lee, M. J., \& Shin, J. Y. (2020). Yuchiwon wongyeogsueob ganeungseong tamsaeg-eul wihan silhaeng-yeongu [Action research for exploring the possibility of distance learning in kindergartens]. Early Childhood Education Research \& Review, 24(5), 277302. https:// doi.org/10.32349/ECERR.2020.10.24.5.277

Lee, M. Y. (2017). An investigation of the predictive power of technostress creators in job satisfaction and teacher efficacy of primary school teachers in Korea [Master's thesis, Ehwa Womans University].

Lee, S. H. (2015). Haggyo gyoyughwangyeong-eseo seumateugigi sayong-e ttaleun hagsaeng-gwa gyosaui tekeunoseuteuleseuwa haengboggam insig yeongu [A study on the perception of students and teachers concerning technostress and happiness depending on the use smart devices in a school educational environment] [Doctoral dissertation, Sungkyunkwan University].

Lee, S. M., \& Pang, J. E. (2015). Boyuggyosaui jigmuseuteuleseuwa ijig-uidoui gwangyeeseo jaatanlyeogseong-ui maegaehyogwa [The mediating effect of ego resilience on correlation between job stress and turnover intention]. Journal of Future Early Childhood Education, 22(3), 83-104.

Lee, Y., Chang, C., Lin, Y., \& Cheng, Z. (2014). The dark side of smartphone usage: Psychological traits, compulsive behavior and technostress. Computers in Human Behavior, 31, 373-383. https://doi.org/10.1016/j.chb.2013.10.047

Lee, Y. S., \& Yang, D. K. (2016). Seumateuleoning hwal-yong-e daehan yuagyosaui insig. [A study on kindergarten teachers' recognition of the use of smart-learning]. Study of Children's Literature $\mathcal{E}$ Education, 17, 629-652. https://doi.org/10.22154/JCLE.17.4.27 
Lindsay, P., \& Lindsay, C. H. (1984). Teachers in preschools and childcare centers: Overlooked and overvalued. Child and Youth Care Quarterly, 16(2), 91-105. https://doi.org/10.1007/BF01083974

Mo, Y. H., \& Kim, K. S. (2013). Yuagyosaui gyojigjeonmunseong-gwa gyojigsinnyeom-e gwanhan insig yeongu [A study on the preschool teacher's perception of teaching professionalism and conviction]. The Journal of Korea Open Association for Early Childhood Education, 18(1), 241-260

Myung, J. H. (2006). Boyuggyosaui sahoejeog jijiwa jigmuseuteuleseu, jeonmunseong insiggwaui gwangye [The relation of the social support for childcare center teacher with job stress and perception on professionalism] [Master's thesis, Sookmyung Women's University].

Nicholson, S., \& Reifel, S. (2011). Sink or swim: Child care teachers' perceptions of entry training experiences. Journal of Early Childhood Teacher Education, 32(1), 5-25. https://doi.org/10.1080/10901027.2010.547650

No, J. H. (2013). Yeong-yuagyosaui jeonmunseong insiggwa jigmumanjog sujun-e gwanhan yeongu [A study on the perception of teaching professionalism and job satisfaction among early childhood teachers]. Journal of Early Childhood Education \& Educare Welfare, 17(2), 74-93.

Park, B. D., Kim, K. R., \& Oh, J. Y. (2018). Yuagyesa-yei hyeiboktanreokseonge yeonghyangeul michinyn gwanlenbunin tamsek [A study on the effects of related variables of child teachers' resilience]. Korean Journal of Children's Media 17(1), 131. https://doi.org/10.21183/kjcm.2018.03.17.1.1

Park, E. H., \& Jun, S. B. (2010). Yuchiwon gyosaui hoebogtanlyeogseong-e yeonghyangeul michineun wiheom-yoingwa bohoyoin tamsaeg [The investigation of risk factors and protective factors that influence resilience in kindergarten teachers]. The Journal of Korean Teacher Education, 27(1), 253-275. https://doi.org/10.24211/tjkte.2010.27.1.253

Park, H. J. (1996) Jaatanlyeogseong-e ttalun gijakdeon stress, daecheu mit uul [Perceived stress, coping and depression according to ego-resilience] [Master's thesis, Korea University].

Park, I. S., \& Bae, J. H. (2020). Jang-aeatonghab-eolin-ijib-ui kolona19 daeeung gwanlyeon wonjang-ui eolyeoumgwa jiwon-yogu [Difficulties and support needs of directors on inclusive childcare centers due to COVID-19]. Korea Journal of Child Care and Education. 125, 1-23. https://doi.org/10.37918/kce.2020.11.125.1

Price, S. (2020, April 10). Teachers grapple with online classes as South Korea goes back to school. Forbes. https://www.forbes.com/sites/steveprice/2020/04/10/teachersgrapple- with-online-classes-as-south-korea-goes-back-to-school/\#688cd8e61386

Ragu-Nathan, T. S., Tarafdar, M., Ragu-Nathan, B. S., \& Tu, Q. (2008). The consequences of technostress for end users in organizations: conceptual development and empirical validation. Information Systems Research, 19(4), 417-433. https://doi.org/10.1287/isre.1070.0165

Sandilos, L. E., Goble, P., Rimm-Kaufman, S. E., \& Robert, C. (2018). Does professional development reduce the influence of teacher stress on teacher-child interactions in pre-kindergarten classrooms? Early Childhood Research Quarterly, 42, 280-290. https://doi.org/10.1016/j.ecresq.2017.10.009

Shim, S. Y., \& Shim, M. Y. (2019). Yuagyosaui jeonmunseong insiggwa yuaui munjehaengdong gan-ui gwangyeeseo yuagyosaui gyosuhyoneung-gamgwa bujeongjeog hun-yugbangsig-ui sunchajeog maegaehyogwa [The sequential mediation effects of teachers' teaching efficacy and discipline styles between teachers' professional recognition and children's behavioral problems]. Journal of 
Future Early Childhood Education, 26(2), 121-140. https://doi.org/10.22155/JFECE.26.2.121.140

Tarafdar, M., Tu, Q., Ragu-Nathan, B. S., \& Ragu-Nathan, T. S. (2007). The impact of technostress on role stress and productivity. Journal of Management Information System 24(1), 301-328. https://doi.org/10.2753/MIS0742-1222240109

Weil, M. M., \& Rosen, L. D. (1997). TechnoStress: Coping with technology@work @home@play. New York: J. Wiley.

Wi, S. H. (2008). Boyuggyosawa yuchiwongyosaui jeonmunseong insig yeongu [Comparing early childhood teachers' professionalism between daycare and kindergarten teachers] [Master's thesis, Sookmyung Women's University].

Yang, I. A., \& Paik, Y. S. (2017). Yeong-yua gyosaui uisasotongneunglyeog mich wonjanggyosawaui gyohwan gwangyega ijig-uido-e michineun yeonghyang-eseo hoebogtanlyeogseong-ui maegaehyogwa [The mediating effect of resilience on early childhood teachers' communication ability, and the director-teacher exchange on turnover intention]. The Journal of Korea Open Association for Early Childhood Education, 22(6), 119-142. https://doi.org/10.20437/KOAECE22-6-06

Yoo, K. J., Kim, M. K., Lee, J. S., \& Han, M. O. (2013). Dijiteolgigi, seumateugigi, seumateu jeonjachaeg-e daehan yuagyosaui insig mich hyeonhwang [An analysis on early childhood teachers' awareness of digital equipment, smart equipment and smart e-books]. The Journal of Korea Open Association for Early Childhood Education, 18(3), 43-70.

You, J. Y., \& Hwang, H. J. (2014). Yuagyosaui jaatanlyeogseong-gwa jeonmunseong-insigi jigmuseuteuleseue michineun yeonghyang [The effects of ego-resilience and professionalism awareness on occupational stress in early childhood teachers]. Journal of Korean Child Care and Education, 10(1), 131-146. https:// doi.org/10.14698/jkcce.2014.10.1.131

Zhong, R. (2020, March 17). The coronavirus exposes education's digital divide. The New York Times. https://www.nytimes.com/2020/03/17/technology/china-schoolscoronavirus. html 


\section{Appendix}

Measurement

Technostress

\begin{tabular}{|c|c|}
\hline Factor & Questions \\
\hline \multirow{5}{*}{$\begin{array}{l}\text { Techno- } \\
\text { overload }\end{array}$} & 1. I am forced by this technology to work much faster \\
\hline & 2. I am forced by this technology to do more work than I can handle \\
\hline & 3. I am forced by this technology to work with very tight time schedules \\
\hline & 4. I am forced to change my work habits to adapt to new technologies \\
\hline & 5. I have a higher workload because of increased technology complexity \\
\hline \multirow{4}{*}{$\begin{array}{l}\text { Techno- } \\
\text { invasion }\end{array}$} & 6. I spend less time with my family due to this technology \\
\hline & $\begin{array}{l}\text { 7. I have to be in touch with my work even during my vacation due to this } \\
\text { technology }\end{array}$ \\
\hline & $\begin{array}{l}\text { 8. I have to sacrifice my vacation and weekend time to keep current on new } \\
\text { technologies }\end{array}$ \\
\hline & 9. I feel my personal life is being invaded by this technology \\
\hline \multirow{5}{*}{$\begin{array}{l}\text { Techno- } \\
\text { complexity }\end{array}$} & 10. I do not know enough about this technology to handle my job satisfactorily \\
\hline & 11. I need a long time to understand and use new technologies \\
\hline & 12. I do not find enough time to study and upgrade my technology skills \\
\hline & $\begin{array}{l}\text { 13. I find new recruits to this organization know more about computer } \\
\text { technology than I do }\end{array}$ \\
\hline & 14. I often find it too complex for me to understand and use new technologies \\
\hline \multirow{5}{*}{$\begin{array}{l}\text { Techno- } \\
\text { insecurity }\end{array}$} & 15. I feel constant threat to my job security due to new technologies \\
\hline & 16. I have to constantly update my skills to avoid being replaced \\
\hline & 17. I am threatened by co-workers with newer technology skills \\
\hline & 18. I do not share my knowledge with my co-workers for fear of being replaced \\
\hline & $\begin{array}{l}\text { 19. I feel there is less sharing of knowledge among co-workers for fear of being } \\
\text { replaced }\end{array}$ \\
\hline \multirow[t]{4}{*}{$\begin{array}{l}\text { Techno- } \\
\text { uncertainty }\end{array}$} & $\begin{array}{l}\text { 20. There are always new developments in the technologies we use in our } \\
\text { organization }\end{array}$ \\
\hline & 21. There are constant changes in computer software in our organization \\
\hline & in computer hardware in our organization \\
\hline & quent upgrades in computer networks in our organization \\
\hline
\end{tabular}

Professionalism perception

\begin{tabular}{|c|c|}
\hline Factor & Questions \\
\hline \multirow{4}{*}{$\begin{array}{l}\text { Knowledge } \\
\text { and skill }\end{array}$} & 1. Early childhood teachers require a high level of teaching ability \\
\hline & $\begin{array}{l}\text { 2. Early childhood teachers should continue to study new and unique } \\
\text { methods of guidance for the development of children }\end{array}$ \\
\hline & 3. I am voluntarily participating in various training sessions or classes \\
\hline & $\begin{array}{l}\text { 4. Early childhood teaching is a job that requires long-term professional } \\
\text { education }\end{array}$ \\
\hline \multirow[t]{4}{*}{ Social service } & 5. Early childhood teaching is important for future societies \\
\hline & $\begin{array}{l}\text { 6. I have a spirit of service to which I can devote even if the early childhood } \\
\text { teaching position is underpaid. }\end{array}$ \\
\hline & $\begin{array}{l}\text { 7. Our institution is trying to benefit local adults by providing parent } \\
\text { education }\end{array}$ \\
\hline & $\begin{array}{l}\text { 8. The facilities and human resources of our early childhood education } \\
\text { institution are open to the community }\end{array}$ \\
\hline \multirow[t]{3}{*}{ Autonomy } & 9. My mission is being accomplished without interference from the boss \\
\hline & 10. I believe classroom classes are left to my autonomy \\
\hline & $\begin{array}{l}\text { ctively participating in important decisions or } \\
\text { dhood education institutions }\end{array}$ \\
\hline
\end{tabular}


12. I am responsible for the incidents in my class

\begin{tabular}{|c|c|}
\hline ed & $\begin{array}{l}\text { 13. The people around me are concerned about the importance of the early } \\
\text { childhood teacher's profession }\end{array}$ \\
\hline & 14. There are times when I feel that a childcare teacher is a nanny \\
\hline & $\begin{array}{l}\text { 15. I think it is important for early childhood teachers to protect and educate } \\
\text { children }\end{array}$ \\
\hline & $\begin{array}{l}\text { 16. I think professional organizations are needed to improve professionalism } \\
\text { in teaching }\end{array}$ \\
\hline & $\begin{array}{l}\text { 17. I believe that standards for licensing early childhood teachers should be } \\
\text { strengthened to improve professionalism }\end{array}$ \\
\hline & $\begin{array}{l}\text { ed to strengthen the qualification criteria for teachers } \\
\text { dhood education }\end{array}$ \\
\hline Worl & 19. Early childhood teachers require high ethical standards of conduct \\
\hline & $\begin{array}{l}\text { 20. I believe that I am committed to my role by defining my own practice as } \\
\text { an early childhood teacher }\end{array}$ \\
\hline & $\begin{array}{l}\text { ig the private information of children is one of the } \\
\text { ly childhood teachers }\end{array}$ \\
\hline & 22. I have no regrets about choosing an early childhood teacher job \\
\hline $\begin{array}{l}\text { economic } \\
\text { status }\end{array}$ & $\begin{array}{l}\text { well paid compared to other jobs that can have the same } \\
\text { ground }\end{array}$ \\
\hline & $\alpha$ the working conditions are good \\
\hline & $\begin{array}{l}\text { lat the teaching position in } \\
\text { able }\end{array}$ \\
\hline
\end{tabular}

11.3. Ego resilience

Factor Questions

Confidence 1 . I tend to give up easily when I encounter a difficult problem

2. I cannot wait to give up if things do not work out

3. I lack confidence

4. I have difficulty concentrating compared to others

5. I am caught up in useless thoughts

6. I sometimes feel like I cannot make it

7. I have not lived my life right

Efficiency of 8. I am embarrassed when I am with strangers

interpersonal 9. I do not like to talk a lot unless I know someone well

relationships 10 . It is hard for me to talk to strangers

11. It is hard for me to talk in front of the class

12. I cannot think of what would be appropriate to talk about when there are a lot of people around me

13. It is hard to tell someone about me

14. I'm not sure I can lead others well

\begin{tabular}{|c|c|}
\hline \multirow{7}{*}{$\begin{array}{l}\text { Optimistic } \\
\text { attitude }\end{array}$} & 15. It seems to me that there is no hope for the future \\
\hline & 16. I have a feeling that I am useless \\
\hline & 17. I'm not as happy as other people think \\
\hline & 18. I feel that my life is meaningless \\
\hline & 19. I have a feeling something terrible is about to happen to me \\
\hline & 20. I have a feeling that the world is just passing by \\
\hline & 21. I feel like I made a mistake in choosing a job \\
\hline \multirow[t]{2}{*}{ Anger control } & 22. I often get angry \\
\hline & 23. When I'm angry, I lose my temper \\
\hline
\end{tabular}

http://ijlter.org/index.php/ijlter 